Краснопьоров П. В., аспірант Народна украӥнська академія м. Харків, Украӥна

DOI: https://doi.org/10.30525/978-9934-26-080-3-3

\title{
МОДЕРНІЗАЦІЯ ЕКОНОМІКИ У КИТАЇ НА СУЧАСНОМУ ЕТАПІ
}

Питання модернізації економіки є актуальним для багатьох країн світу, які розвиваються. Протягом останніх десятиліть багато країн Азії демонструють приклади вдалої соціальноекономічної модернізації. Середи таких країн, у тому числі, називають Китай.

У грудні 1978 р. відбувся третій пленум ЦК КПК 11-го скликання. Пленум зробив установку на проведення стратегії «соціалістичної модернізації з китайською специфікою» (有中国特色的社会主义现代化) [1， c. 328]. Насамперед, мова 
йшла про модернізацію сільського господарства, промисловості, оборони, науки та техніки. (四个现代化), що повинно було привести до покращення матеріального стану населення.

Метою модернізації вважається прискорене економічне зростання, якісне оновлення економіки та підвищення пї ефективності на базі розвитку науково-технічного потенціалу. Виходячи 3 того, що наука $\epsilon$ «головна продуктивна сила» (重要生 产力), iї розвиток $є$ важливішою метою економічної розбудови. Постановка мети 3 розвитку науки та техніки пов'язувалась Ден Сяо Піном 3 підвищенням ролі інтелектуальної праці у здійсненні модернізації та взагалі положенню інтелігенції у суспільстві [2, с. 190].

Протягом усього періоду, починаючи 31978 р. Китай робив помітні кроки у розвитку науки, техніки, нових технологій. Наприклад, кількість фахівців, які займаються науково-технічними розробками у Китаї постійно зростала (на 1млн. населення у 1996 році було 437,8 фахівців, а у 2018 році - вже 1307,1 фахівця).

Таблиця 1

Кількість фахівців, які займаються науково-технічними розробками (Research and Development) у Китаї

(на 1 мільйон населення)

\begin{tabular}{|c|c|}
\hline PIK & Кількість фахівців \\
\hline 1996 & 437,8 \\
\hline 2000 & 538,6 \\
\hline 2005 & 840,6 \\
\hline 2010 & 884,6 \\
\hline 2015 & 1150,8 \\
\hline 2018 & 1307,1 \\
\hline
\end{tabular}

Джерело: [3]

За індексом інновації (Innovation Index) - 53,3 Китай займав вже 14-те місце у світі [4] серед 133 країн які були проіндексовані за цим показником. 
Доля сільського господарства у ВВП постійно скорочується, проте стабільно збільшується доля сектору послуг, - якщо у 1980 році доля сільського господарства у виробництві ВВП складала $29,63 \%$, то у 2000 році - $14,68 \%$, а у 2019 році - вже $7,11 \%$ [5]. У той час як доля сектору послуг постійно збільшується: 1980 р. - 22,31\%, 2000 р. - 39,79\%, 2019 р. - 53,92\% [6].

Зайнятість у сільському господарстві постійно зменшувалась, у той час, як виробництво сільськогосподарської продукції швидко зростало. У 1991 році у сільському господарстві у КНР було зайнято 59,7\% економічно активного населення, у 2000 р. $50,01 \%$, а у 2019 році $-25,33 \%$ [7].

У той час, як виробництво сільськогосподарської продукції (у грошовому еквіваленті) складало [8]:

- 1990 - 95,93млрд. дол.;

- 2000 - 177,78 млрд. дол.;

- 2010 - 567,74 млрд. дол.;

- 2019 - 1020,01 млрд. дол.

У рамках політики «чотирьох модернізацій» вирішувалось багато соціальних проблем. Протягом усього періоду «Політики реформ та відкритості» у Китаї постійно зменшувався рівень бідності. Якщо у 1990 році відсоток населення, який жив менш ніж на 1,90 долара у день складав $66,3 \%$, то у 2016 році така частка склала вже лише $0,5 \%$ усього населення країни [9]. Частка населення яка живе менш ніж на 5,50 долара США у день скоротилась $398,3 \%$ у 1990 році до $24 \%$ у 2016 році [10].

Постійно збільшувалися витрати на науково-дослідні та дослідно-конструкторські роботи (НДДКР), як відсоток ВВП.

Таблиця 2

Частка ВВП, яка витрачається на дослідження та розробки [11]

\begin{tabular}{|c|c|}
\hline Рік & Відсоток ВВП який витрачасться на НДДКР \\
\hline 1996 & 0,56 \\
\hline 2000 & 0,89 \\
\hline 2010 & 1,71 \\
\hline 2018 & 2,19 \\
\hline
\end{tabular}


Постійно збільшується кількість заявок на патенти у країні.

Таблиця 3

Кількість заявок на патенти у Китаї[12]

\begin{tabular}{|c|c|}
\hline Рік & Кількість заявок на патенти \\
\hline 1992 & 10022 \\
\hline 2000 & 25346 \\
\hline 2010 & 293066 \\
\hline 2018 & 1393815 \\
\hline
\end{tabular}

32011 року питома вага експорту високотехнологічної продукції у валовому експорті, залишається у межах $30 \%$. Це результат не лише безпосереднього фінансування науки та технологій $з$ державного бюджету, але й політики стимулювання розвитку інновацій за допомогою надання бізнесу різного роду пільг. До них відносяться:

1. Підприємствам високотехнологічного виробництва надаються пільги зі сплати податку на прибуток: якщо загальна ставка податку у країні складає 25\%, то для цих компаній передбачена знижена ставка податку $-15 \%$.

2. Для малих та середніх науково-технічних підприємств передбачене додаткове податкове вирахування за витратами на НДДКР, яке складає 75\%.

3. Для громадян інших країн, які працюють у іноземних компаніях або компаніях 3 іноземною участю на території КНР (як правило, це висококваліфіковані трудові ресурси), передбачені вирахування окремих витрат 3 податкової бази за податком на фізичні особи.

4. У відношенні науково-дослідницького персоналу підприємствам надається можливість вираховувати 3 податкової бази витрати компаній $з$ п'яти видів страхування (пенсійне, медичне, страхування від безробіття, від травм на виробництві, страхування на випадок народження дитини) та суми, які перераховуються у суспільний Фонд житлового страхування.

Пошук оптимальної стратегії розвитку, обговорюваний в китайському суспільстві, знайшов своє відображення на 
XIX з’ізді КПК. Самою «гучною» подією з’їзду стало внесення до Статуту партії ідей Сі Цзінпіну під загальною назвою «Соціалізм 3 китайською специфікою в нову епоху». Під «новою епохою» розуміється новий виток у розвитку Китаю і його ролі в світі. Основними цілями КНР в «новій епосі» є:

1. Побудова суспільства «середньої заможності».

2. Будівництво вдосконаленого соціалізму.

3. Відродження великої китайської нації.

4. Підвищення ролі КНР у світі.

5. Участь Китаю у «розвитку людства» [13, с. 148].

Протягом останніх років спостерігається поступове уповільнення темпів економічного зростання у Китаї: якщо у 2010 році зростання ВВП склало 10,6\%, то вже у 2019 році - 6,1\% [14]. У відповідності до цього КНР переходить від кількісних показників зростання до якісних, що пов'язане 3 необхідністю оптимізації економічної структури та створення нових драйверів розвитку. На XIX з’ізді КПК обговорювались окремі заходи, спрямовані на перехід економіки Китаю на «інноваційні рейки»:

- омолодження сільського населення;

- будівництво «екологічної цивілізації»;

- створення державного управління активами природних ресурсів та природоохоронного регулюючого органу;

- розширення повноважень місцевих органів влади у відношенні взаємодії з місцевим бізнесом;

- продовження антикорупційної політики;

- покращення інтернет-технологій, створення кіберпростору;

- розвиток експериментальних зон вільної торгівлі;

- побудова нового типу міжнародного співробітництва, заснованого на взаємній вигоді, справедливості, рівності та взаємної повазі [15, с. 150].

Досвід КНР у модернізації економіки може бути корисним для багатьох країн світу (у тому числі в Україні). 


\section{Література:}

1. Сизикова В.А. Политика социалистической модернизации в Китае после 1978 года: шансы и вызовы. Социально-гуманитарные знания. 2006. № 1. C. $328-341$.

2. Регзенова Дулма Бато-Очировна. Основные принципы и сущность реформ Дэн Сяопина. Вестник Бурятского государственного университета. Педагогика. Филология. Философия. 2010. № 6. С. 189-193.

3. World Development Indicators. Data Bank: веб-сайт. URL: https://databank.worldbank.org/source/world-development-indicators\# (дата звернення: 02.05.2021).

4. Innovation index - Country rankings. the globaleconomy.com: веб-сайт. URL: https://www.theglobaleconomy.com/rankings/GII_Index/ (дата звернення: 02.05.2021).

5. China: GDP share of agriculture. the globaleconomy.com: веб-сайт. URL: https://www.theglobaleconomy.com/China/Share_of_agriculture/ (дата звернення: 03.05.2021).

6. China: Share of services. the globaleconomy.com: веб-сайт. URL: https://www.theglobaleconomy.com/China/Share_of_services/ (дата звернення6 03.05.2021).

7. China: Employment in agriculture. the globaleconomy.com: веб-сайт. URL: https://www.theglobaleconomy.com/China/Employment_in_agriculture/ (дата звернення: 03.05.2021).

8. China: Agriculture value added. the globaleconomy.com: веб-сайт. URL: https://www.theglobaleconomy.com/China/value_added_agriculture_dollars/ (дата звернення: 04.05.2021).

9. China: Poverty at 1.90 USD per day. the globaleconomy.com: веб-сайт. URL: https://www.theglobaleconomy.com/China/poverty_ratio_low_range/ (дата звернення 04.05.2021).

10. China: Poverty at 5.50 USD per day. the globaleconomy.com: веб-сайт. URL: https://www.theglobaleconomy.com/China/poverty_ratio_high_range/ (дата звернення: 04.05.2021).

11. China: Research and development expenditure. the globaleconomy.com: вебсайт. URL: https://www.theglobaleconomy.com/China/Research_and_development/ (дата звернення: 04.05.2021).

12. China: Patent applications by residents. the globaleconomy.com: веб-сайт. URL: https://www.theglobaleconomy.com/China/Patent_applications_by_residents/ (дата звернення: 04.05.2021).

13. Колесникова Т.В., Оводенко А.А. Развитие экономики КНР в «новой эпохе»: результаты XIX съезда коммунистической партии Китая. Проблемы современной экономики. 2018. № 1 (65). С. 148-152.

14. China GDP - Gross Domestic Product. the countryeconomy.com: веб-сайт. URL: https://countryeconomy.com/gdp/china (дата звернення: 06.05.2021). 